\title{
A Comparison of Effective Tension Calculation for Design Belt Conveyor between CEMA and DIN Standard
}

\author{
Iman Satria ${ }^{1}$, Meifal Rusli ${ }^{2}$ \\ 1, Mechanical Department Engineering, Faculty of Industry Technology, University of Bung Hatta Padang-Indonesia, \\ ${ }^{2}$ Mechanical Department Engineering, Faculty of Engineering,University of Andalas Padang-Indonesia,
}

\begin{abstract}
In the present era, many industries are demanding material transfer equipment that works maximally and cheaply. Belt Conveyor is one of the most efficient material transfer equipment compared to heavy equipment or other transportation equipment, because it can transport the material in large capacity. When designing conveyor belts, many industries want large transport capacity at low cost. One of the cost savings can be done with low motor power consumption. Many standards describe the effective tension calculation on the conveyor belt in detail with the parameters, since the effective tension calculation results are essential for determining motor power. This paper aims to analyze the effective tension on conveyor belts using CEMA 5th, CEMA 6th and DIN 22101 standards with case studies of $1000 \mathrm{TPH}$ carrying capacity and $3 \mathrm{~m} / \mathrm{s}$ conveyor speed. The difference between CEMA and DIN when determining the effective tension is on the use of coefficient of friction, because DIN uses a global coefficient of friction while CEMA uses different friction coefficients on idler, belt and material. This difference in coefficient of friction results in different ways of calculating the resistance being the accumulation of the effective tension. The result is an effective tension value using DIN 22101 standard of 22,148.16 N with motor power consumption of 66.5 $\mathrm{kW}$, while effective tension value using CEMA $5^{\text {th }}$ standard is $32.201 .66 \mathrm{~N}$ with motor power consumption $96.47 \mathrm{~kW}$, and effective tension value using CEMA $6^{\text {th }}$ standard is $29,686.48 \mathrm{~N}$ with $89.06 \mathrm{~kW}$ motor power consumption.
\end{abstract}

\section{Introduction}

Material transport equipment is very important in this modern era of life, especially in helping a job to obtain maximum results. Material transport equipment serves to move material in certain areas, to a department, plant and plant, construction site, storage and loading.

Today, they are in most cases the most costeffective solution for handling bulk material mass flow over short and medium conveying distances. Despite the already advantageous costs for belt conveyor operation, there is still a desire to reduce these costs even futher [9]. One of the cost savings can be done with low motor power consumption, where the motor power value is directly proportional to the effective tension value that occurs in a conveyor system.

Effective tension is defined as the sum of all the resistance of motion referring to the motor [6]. The resistances that affect the effective tension are friction resistance due to friction between the belt, idler and material when the conveyor belt is running. In addition, the energy resistance or resistance caused by the load carried by the conveyor itself is a resistance that also refers to the motor.

In determining the effective tension of the conveyor belt, there are many standards that can be noticed by engineer such as; CEMA, DIN 22101, and so forth.
Standard is a norm which is usually a formal document that creates uniform engineering or technical criteria, methods, processes and practices. The two most common design methods used to calculate the effective tension on the conveyor belt are the Conveyor Equipment Manufacturer's Association (CEMA) method [1] [2] and the Deutsches Institute Normung (DIN) method DIN 22101 Standard [3].

Based on these problems, it is necessary to conduct research that aims to analyze the effective tension on the conveyor belt using standard variations DIN 22101, CEMA $5^{\text {th }}$, and CEMA $6^{\text {th }}$. Problems to be investigated in this research include: effective tension calculation analysis on belt conveyor capacity $1000 \mathrm{TPH}$ using standard DIN 22101, CEMA 5th, and CEMA 6th, and determine difference of three standard in determining effective tension.

\section{Belt conveyor data}

In this research, an effective tension calculation analysis using CEMA standard and DIN 22101 standard with case study on conveyor capacity of 1000 ton / hour. Study of case in this research using data conveyor at PT. Pelabuhan Indonesia (Pelindo) II Bengkulu as above in 
table 1. Using the data obtained we will analyze the differences between the DIN 22101, CEMA 5th, and CEMA 6th standard in designing and analyzing the effective tension to determine the motor power of the conveyor system.

Table 1. Conveyor industrial data

\begin{tabular}{|l|c|c|}
\hline \multicolumn{1}{|c|}{ Parameter } & $\begin{array}{c}\text { Value ( S.I } \\
\text { Units) }\end{array}$ & $\begin{array}{c}\text { Value } \\
\text { (British } \\
\text { Units) }\end{array}$ \\
\hline Length along belt & $154 \mathrm{~m}$ & $505 \mathrm{ft}$ \\
\hline Lift & $17 \mathrm{~m}$ & $56 \mathrm{ft}$ \\
\hline Angle of Incline & $6.30^{\circ}$ & $6.30^{\circ}$ \\
\hline Belt Width & $1.2 \mathrm{~m}$ & $48 \mathrm{in}$ \\
\hline Skirt width & $0.8 \mathrm{~m}$ & $31.48 \mathrm{in}$ \\
\hline Capacity & $1000 \mathrm{tph}$ & $1000 \mathrm{tph}$ \\
\hline Belt Speed & $2.5 \mathrm{~m} / \mathrm{s}$ & $492 \mathrm{ft}$ \\
\hline Bulk Density & $0.96 \mathrm{ton} / \mathrm{m}^{3}$ & $60 \mathrm{lbf} / \mathrm{ft}^{3}$ \\
\hline Carry idler spacing & $1.2 \mathrm{~m}$ & $4 \mathrm{ft}$ \\
\hline $\begin{array}{l}\text { Drive pulley wrap } \\
\text { angle }\end{array}$ & $210^{\circ}$ & $210^{\circ}$ \\
\hline Coefficient friction & 0.35 & 0.35 \\
\hline Pulley/ belt) & $0.0144 \mathrm{~m}$ & $0.567 \mathrm{in}$ \\
\hline Nolt Thickness & $139 \mathrm{~mm}$ & $5.5 \mathrm{in}$ \\
\hline length of skirtboard & $6.456 \mathrm{~m}$ & $21.18 \mathrm{ft}$ \\
\hline
\end{tabular}

\section{Result and discuss}

\subsection{Comparison of Coefficient for DIN 22101, CEMA 5th and CEMA 6th Standard}

The fundamental difference between DIN 22101 and CEMA $5^{\text {th }}$ is on the use of friction factor, where the DIN 22101 standard uses a single or

\begin{tabular}{|c|c|c|}
\hline $\begin{array}{l}\text { No. of roll per idler } \\
\text { set }\end{array}$ & 3 & 3 \\
\hline Troughing angle & $35^{\circ}$ & $35^{\circ}$ \\
\hline $\begin{array}{l}\text { Material Surcharge } \\
\text { Angle }\end{array}$ & $20^{\circ}$ & $20^{\circ}$ \\
\hline Angle of Repose & $35^{\circ}$ & $35^{\circ}$ \\
\hline Idler Misalignment & 0 & 0 \\
\hline No. of drive pulley & 1 & 1 \\
\hline $\begin{array}{l}\text { Diameter of drive } \\
\text { pulley }\end{array}$ & $660 \mathrm{~mm}$ & 26 in \\
\hline $\begin{array}{l}\text { Shaft Diameter of } \\
\text { Drive Pulley }\end{array}$ & $136 \mathrm{~mm}$ & $5.35 \mathrm{in}$ \\
\hline $\begin{array}{l}\text { Weight of Drive } \\
\text { Pulley }\end{array}$ & $16000 \mathrm{~N}$ & $\begin{array}{l}3596.94 \\
\text { lbf }\end{array}$ \\
\hline $\begin{array}{l}\text { No. of Snub/Bend } \\
\text { pulley }\end{array}$ & 5 & 5 \\
\hline $\begin{array}{l}\text { Diameter } \\
\text { Snub/Bend pulley }\end{array}$ & $420 \mathrm{~mm}$ & 15.53 in \\
\hline $\begin{array}{l}\text { Shaft Diameter } \\
\text { Snub/Bend pulley }\end{array}$ & $80 \mathrm{~mm}$ & 3.149 in \\
\hline $\begin{array}{l}\text { Weight of } \\
\text { Snub/Bend pulley }\end{array}$ & $8000 \mathrm{~N}$ & $\begin{array}{c}1798.47 \\
\mathrm{lbf}\end{array}$ \\
\hline Take-up tension & $40754.95 \mathrm{~N}$ & $9162 \mathrm{lbf}$ \\
\hline Type of belt used & \multicolumn{2}{|c|}{$\begin{array}{l}\text { Fabric Belt 1200-EP 630/ } \\
\text { 4ply } 6+3\end{array}$} \\
\hline $\begin{array}{l}\text { Type of idler } \\
\text { bearing used }\end{array}$ & \multicolumn{2}{|c|}{ Ball bearing } \\
\hline Bulk Material & \multicolumn{2}{|c|}{ Coal (Antrhacite Sized) } \\
\hline
\end{tabular}

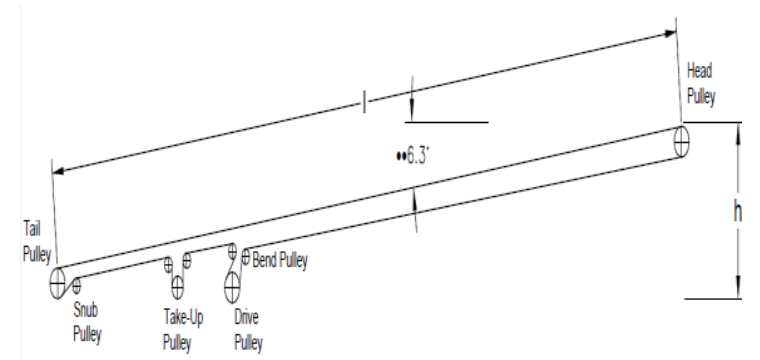

Figure 1. Scheme of conveyor

To analyze the effective tension calculation performed using computer program that is MATLAB 2008a.

global friction factor (f) while the CEMA $5^{\text {th }}$ standard distinguishes the coefficient of friction on idlers, belts, and materials ( $\mathrm{Kx}$ and $\mathrm{Ky})$. While CEMA $6^{\text {th }}$ further refine the friction factor of CEMA $5^{\text {th }}$, where $K_{x}$ is changed to $K_{i s}, K_{i v}$ and $C_{i W}$. The coefficient of friction is useful for calculating resistance due to friction that occurs in the belt, idler and material. 
Table 2. Comparison of Coefficient for DIN 22101, CEMA $5^{\text {th }}$, and CEMA $6^{\text {th }}$ methods.

\begin{tabular}{|c|c|c|c|}
\hline Variable & DIN 22101 & CEMA $5^{\text {th }}$ & CEMA $6^{\text {th }}$ \\
\hline \multirow{4}{*}{ Friction Factor } & \multirow{4}{*}{$\mathrm{f}$} & \multirow{3}{*}{$\mathrm{K}_{\mathrm{x}}$} & $\mathrm{K}_{\mathrm{Iv}}$ \\
\hline & & & $\mathrm{K}_{\text {is }}$ \\
\hline & & & $\mathrm{C}_{\mathrm{iW}}$ \\
\hline & & $\mathrm{K}_{\mathrm{y}}$ & $\mathrm{T}_{\mathrm{bi}}, \mathrm{T}_{\mathrm{im}}, \mathrm{T}_{\mathrm{mz}}$ \\
\hline $\begin{array}{l}\text { Factor Correction } \\
\text { Temperature }\end{array}$ & $\mathrm{ct}$ & $\mathrm{K}_{\mathrm{t}}$ & $\mathrm{K}_{\mathrm{iT}}$ \\
\hline \multirow{5}{*}{ Primary Tension } & \multirow{5}{*}{$\mathrm{F}_{\mathrm{H}}$} & \multirow{2}{*}{$\mathrm{T}_{\mathrm{x}}$} & $\mathrm{T}_{\text {is }}$ \\
\hline & & & $\mathrm{T}_{\mathrm{iW}}$ \\
\hline & & $\mathrm{T}_{\mathrm{yc}}$ & $\mathrm{T}_{\mathrm{bi}}$ \\
\hline & & $\mathrm{T}_{\mathrm{yr}}$ & $\mathrm{T}_{\mathrm{im}}$ \\
\hline & & $\mathrm{T}_{\mathrm{ym}}$ & $\mathrm{T}_{\mathrm{mz}}$ \\
\hline \multirow{2}{*}{ Secondary Tension } & \multirow{2}{*}{$\mathrm{F}_{\mathrm{N}}$} & $\mathrm{T}_{\mathrm{p}}$ & $\mathrm{T}_{\mathrm{p}}$ \\
\hline & & $\mathrm{T}_{\mathrm{ac}}$ & $\mathrm{T}_{\mathrm{ac}}$ \\
\hline Secondary Tension Factor & $\mathrm{C}$ & - & - \\
\hline \multirow{2}{*}{ Gradient Tension } & \multirow{2}{*}{$\mathrm{F}_{\mathrm{St}}$} & $\mathrm{T}_{\mathrm{m}}$ & $\mathrm{T}_{\mathrm{H}}$ \\
\hline & & $\mathrm{T}_{\mathrm{am}}$ & $\mathrm{T}_{\mathrm{am}}$ \\
\hline
\end{tabular}

\section{For DIN 22101 methods,}

ct $=$ Temperature correction factor, where (ct $=1$ at $20^{\circ} \mathrm{C}$, ct $=1.7$ at $\mathrm{T}=-40^{\circ} \mathrm{C}$ )

$\mathrm{f}=$ Friction factor, value $0.01<\mathrm{f}<0.04$, based on operation and installation conditions.

$\mathrm{C}=$ Secondary tension factor, based on conveyor length $(\mathrm{C}=1.92$ at $80 \mathrm{~m}, \mathrm{C}=1.05$ at $>2 \mathrm{~km})$

\section{For CEMA $5^{\text {th }}$ methods,}

$\mathrm{Kx}=$ Idler friction factor (See the CEMA equation)

$\mathrm{Ky}=$ Belt and material flexure factor (0.016 to 0.035$)$, from CEMA table.

$\mathrm{Kt}=$ Temperature correction factor, where $\mathrm{Kt}=1(0<\mathrm{T}$ $\left.<40^{\circ} \mathrm{C}\right), \mathrm{Kt}=3\left(\mathrm{~T}=-40^{\circ} \mathrm{C}\right)$

\section{For CEMA $6^{\text {th }}$ methods,}

$\mathrm{K}_{\mathrm{is}}=$ Seal torsional resistance per roll $\left(3<\mathrm{K}_{\mathrm{is}}<7.25\right)$ based on the type of idler used.

$\mathrm{K}_{\mathrm{iV}}=$ Torsional speed effect, (0.003 to 0.004$)$, based on the type of idler used.

$\mathrm{K}_{\mathrm{iT}}=$ Temperature correction factor (See the CEMA equation)

$\mathrm{C}_{\mathrm{iW}}=$ Torsional load effect (0.00125 to 0.0029$)$, based on the type of idler and bearing used.

\subsection{Effective tension calculation result}

Base on DIN 22101 methods, the result shown as figure above.

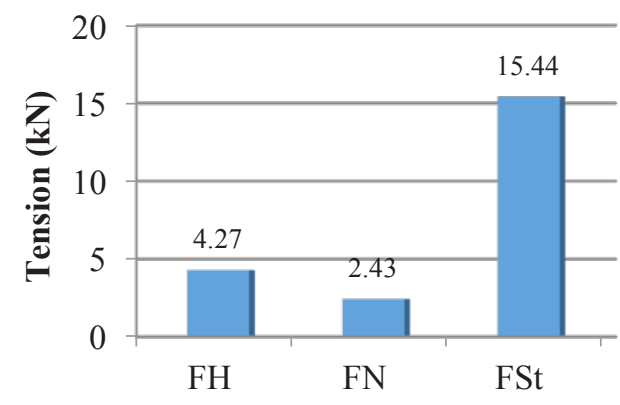

Figure 2. Graph of comparison of tension used DIN 22101 standard

The greatest tension occurs due to the energy load (elevation tension), where the value of the gradient tension (FSt) is $15441.2 \mathrm{~N}$. While the secondary tension (FN) is the smallest tension that occurs with the value of $2433.92 \mathrm{~N}$. The tension due to the primary tension $(\mathrm{FH})$ occurs of $4273.04 \mathrm{~N}$.

CEMA $5^{\text {th }}$ methods,

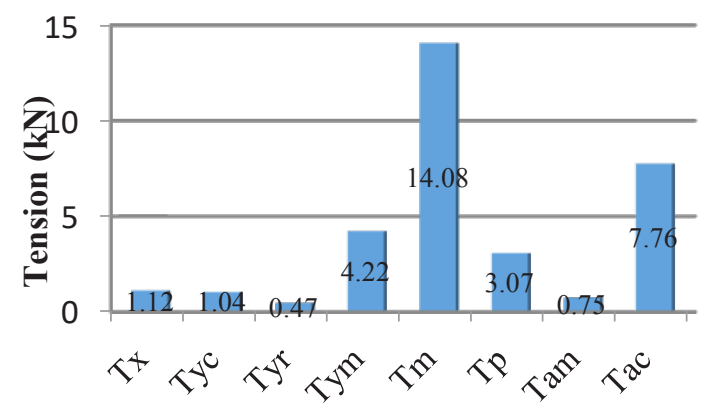

Figure 3. Graph of comparison of tension used CEMA $5^{\text {th }}$ standard 
Fig 3 shows the results of the tension calculations that occur using the CEMA $5^{\text {th }}$ standard, where the greatest energy loss is caused by the tension lift or lower of material (Tm) with a value of $14078.98 \mathrm{~N}$. Tx, Tyc, Tyr, and Tym are the tension caused by friction on the idler, belt and material occurs of $6854.26 \mathrm{~N}$. The tension due to the accessories tension (Tac) occurs of $7763.24 \mathrm{~N}$.

CEMA $6{ }^{\text {th }}$ methods,

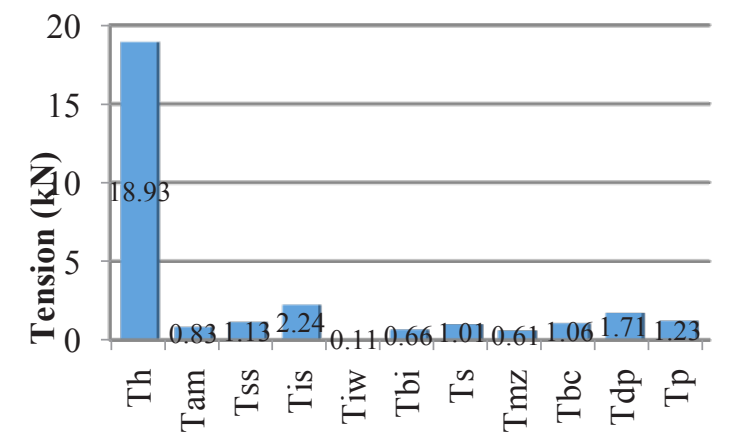

Figure 4. Graph of comparison of tension used CEMA $6^{\text {th }}$ standard
Fig 4 shows the results of the tension calculations that occur using the CEMA $6^{\text {th }}$ standard, where the greatest energy loss is caused by the tension lift or lower of material and belt (Th) with a value of 18926.8 N. Tis, Tiw, Tbi and Tmz are the tension caused by friction on the idler, belt, and materials. The value of tension occurs due to the primary friction on belt conveyor (Tis, Tiw, Tbi and Tmz) is $3629.5 \mathrm{~N}$. While the accessories tension (Tss, Ts, Tbc, Tdp and Tp) is occurs of $6298.33 \mathrm{~N}$.

\subsection{Comparison of Effective Tension Result}

Table 6 shows the comparison of effective tension calculations using DIN 22101, CEMA 5th, and CEMA 6th standards.

The effective tension value is directly proportional to the motor power consumption value, so that the motor power value using DIN 22101 standards is 66.5 $\mathrm{kW}$, the motor power value using CEMA 5th standard is $97.42 \mathrm{~kW}$ and the motor power value using CEMA 6th standard is $89.06 \mathrm{~kW}$. Seen from the three largest energy loss standards caused by the tension of energy (height) and then followed by the primary tension and the smallest is secondary tension.

Table 6. Comparison of effective tension with DIN 22101, CEMA 5, CEMA 6 standard

\begin{tabular}{|c|c|c|c|c|c|c|}
\hline \multirow{2}{*}{ Variable } & \multicolumn{2}{|c|}{ DIN 22101} & \multicolumn{2}{|c|}{ CEMA 5} & \multicolumn{2}{|c|}{ CEMA 6} \\
\hline & Value & Symbols & Value & Symbols & Value & Symbols \\
\hline Primary Tension & $4.27 \mathrm{kN}$ & FH & $6.85 \mathrm{kN}$ & $\begin{array}{c}\text { (Tx+Tyr+ } \\
\text { Tyc+Tym) }\end{array}$ & $3.63 \mathrm{kN}$ & $\begin{array}{l}\text { (Tis+Tiw+ } \\
\text { Tbi+Tmz) }\end{array}$ \\
\hline Secondary Tension & $2.43 \mathrm{kN}$ & $\mathrm{FN}$ & $10.83 \mathrm{kN}$ & $(\mathrm{Tac}+\mathrm{Tp})$ & $6.29 \mathrm{kN}$ & $(\mathrm{Tac}+\mathrm{Tp})$ \\
\hline Gradient Tension & $15.44 \mathrm{kN}$ & FSt & $14.83 \mathrm{kN}$ & (Tm+Tam) & $19.76 \mathrm{kN}$ & $(\mathrm{Th}+\mathrm{Tam})$ \\
\hline Effective Tension & $22.15 \mathrm{kN}$ & $\mathrm{Fw}$ & $32.5 \mathrm{kN}$ & $\mathrm{Te}$ & $29.69 \mathrm{kN}$ & $\mathrm{Te}$ \\
\hline Motor Power & $66.5 \mathrm{~kW}$ & $\mathrm{Pw}$ & $97.42 \mathrm{~kW}$ & $\mathrm{P}$ & $89.06 \mathrm{~kW}$ & $\mathrm{P}$ \\
\hline
\end{tabular}

\subsection{Result of maximum tension calculation with variation capacity using cema standard $6^{\text {th }}$}

The maximum tension is the largest tension that occurs in a conveyor belt system. The purpose of calculate the maximum tension in order to determine the construction specifications according to the maximum load value that occurred. Here is a graph showing the maximum load value on a conveyors variation with a conveyor speed of $3 \mathrm{~m} / \mathrm{s}$.

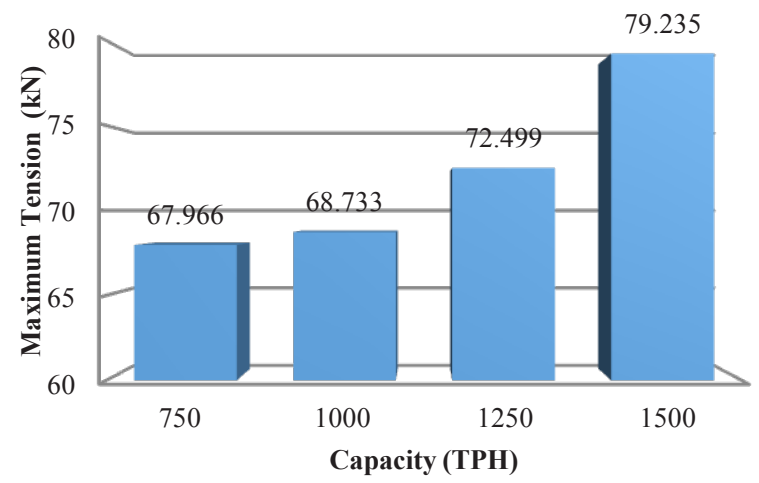

Figure 5. Graph of maximum tension as function capacity of belt conveyor 


\section{Conclusion}

After doing research and data analysis of test result can be concluded that:

1. Effective tension value and lowest motor power consumption is calculation using DIN 22101 standard with effective tension value of $22.15 \mathrm{kN}$ and motor power consumption of $66.5 \mathrm{~kW}$. While the effective tension value and highest motor power consumption is an effective tension calculation using CEMA $5^{\text {th }}$ standard with effective tension value of 32.2 $\mathrm{kN}$ and motor power consumption of $97.42 \mathrm{~kW}$

2. The fundamental difference of the effective tension calculation of CEMA and DIN 22101 is located on the coefficient of friction, where DIN standard uses single friction coefficient (f) while CEMA standard differentiates coefficient of friction on belt, idler, and material $\left(\mathrm{K}_{\mathrm{x}}\right.$ and $\mathrm{K}_{\mathrm{y}}$ ). In CEMA 6th $\mathrm{Kx}$ developed again into $\mathrm{K}_{\mathrm{is}}$, $\mathrm{K}_{\mathrm{iV}}$ and $\mathrm{C}_{\mathrm{iW}}$ to find the voltage on the idler, and $\mathrm{K}_{\mathrm{y}}$ replaced by calculating the tension equation of belt $\left(\mathrm{T}_{\mathrm{bi}}, \mathrm{T}_{\mathrm{im}}, \mathrm{T}_{\mathrm{mz}}\right)$.

3. From the effective tension calculation using the three standards, the highest tension increase is caused by the tension due to the energy.

4. The result of the maximum tension analysis using CEMA 6 standard is directly proportional to the variation of the carrying capacity. Where the greater the carrying capacity it will increase the maximum tension value. The highest maximum tension value is $79.23 \mathrm{kN}$ at the carrying capacity of $1500 \mathrm{TPH}$, while the lowest maximum tension value is $67.96 \mathrm{kN}$ at $750 \mathrm{TPH}$ carrying capacity.

5. In terms of safety calculation results using the CEMA 5 standard is more secure than the standard DIN 22101 and CEMA 6 because it has the highest motor power value with a value of $96.47 \mathrm{~kW}$. However, in terms of economic value, the calculation result using DIN 22101 standard is cheaper compared to CEMA 5 and CEMA 6 standards because it has a much lower motor power value with a value of 66.5 $\mathrm{kW}$.

\section{References}

1. Conveyor Equipment Manufacturers Association (CEMA) 2002. Belt Conveyor for Bulk Materials. $5^{\text {th }}$ Edition.

2. Conveyor Equipment Manufacturers Association (CEMA) 2007. Belt Conveyor for Bulk Materials. $6^{\text {th }}$ Edition.

3. Deutsches Institut fur Normung (DIN) 22101. 2002. Belt Conveyor for Loose Bulk Materials.

4. Gerrard, Bruce dan O'Rourke, L. 2009. Optimisation of overland conveyor performance. Australian Bulk Handling Review.
5. Gupta, A. 2014. An investigation into tensile force of long distance belt conveyor.

6. Horrison, A. 2009. A Comparison of Friction Models for Conveyor Design. Bulk Solid \& Powder - Science Technology Vol. 4 No.1.

7. Kulinowski, P., Kasza, P. Belt Conveyor Calculation. Department of Mining, Dressing and Transport Machines AGH.

8. Kulinowski, P., Kasza, P. Belt Conveyor for Bulk Materials Calculations by CEMA $5^{\text {th }}$ Edition. Department of Mining, Dressing and Transport Machines AGH.

9. Lauhoff, H. 2005. Speed Control on Belt Conveyors - Does it Really Save Energy?. Bulk Solid Handlings Vol. 25 No.6

10. Visser, T. H. A. 2015. Energy Prediction Models of Belt Conveyor System Towards Speed Control. Department Marine and Transport Technology. 